\title{
CIDH saluda histórica decisión del Tribunal Oral Federal de Mendoza, Argentina
}

Washington, D.C. - La Comisión Interamericana de Derechos Humanos (CIDH) aplaude la decisión del Tribunal Federal de Mendoza, Argentina, del 27 de julio de 2017, mediante la cual se condenó a 4 ex operadores de justicia a penas de prisión perpetua e inhabilitación absoluta por su colaboración con los crímenes de lesa humanidad de la dictadura cívico-militar (1976-1983). Esta decisión representa un histórico paso hacia adelante en la lucha contra la impunidad de las graves violaciones a los derechos humanos. Según el fallo de la Corte, los ex jueces federales Rolando Carrizo y Luis Miret, el ex defensor oficial Guillermo Petra Recabarren, y el ex fiscal federal Otilio Romano, fueron partícipes primarios de los crímenes del terrorismo del Estado mientras servían en el Poder Judicial durante la dictadura. Tal fallo consolida la interpretación de que los ex operadores de justicia son responsables activos y directos de la comisión de actos de secuestro, tortura y asesinato. Además, la decisión es histórica en la medida en que representa un avance en la responsabilización de civiles y de otros poderes por los crímenes de la dictadura. "Esta decisión es un importante paso en los avances de la justicia en Argentina y un ejemplo para la región en cuanto a los graves crímenes del pasado. El fallo demuestra que hubo una conducta sistemática también del Poder Judicial argentino de colaboración con el terrorismo de Estado en el pasado", afirmó el Comisionado Paulo Vannuchi, relator a cargo de la nueva Unidad de Memoria, Verdad y Justicia de la CIDH. "En un contexto de amenazas de retroceso en la materia en la región, esta decisión representa un avance en términos de lucha contra la impunidad de civiles. Es necesario fortalecer y avanzar la promoción de la memoria, verdad y justicia en las Américas", agregó el Comisionado Vannuchi. La CIDH saluda este paso hacia la verdad y la justicia, y llama al Estado a continuar con su deber de investigar, juzgar y sancionar a todos aquellos involucrados en la perpetración de graves crímenes y violaciones de derechos humanos. 